\title{
DETERMINANTS OF THE REAL CONVERGENCE PROCESS IN THE EUROPEAN UNION - A PANEL ANALYSIS FOR 2004-2015
}

Convergence in GDP per capita is, undoubtedly, more likely to occur in integration groups and therefore in the group of countries whose economies operate in a similar manner, converging to the same steady state point and creating so-called "convergence clubs". The "traditional" determinants of economic growth (physical and human capital accumulation, changes in Total Factor Productivity) and the "deep" determinants (level of the openness of economies, quality and efficiency of institutions, capital mobility and diffusion of technology) can be regarded as the key causes of that process. The paper presents a review of the theoretical and empirical studies concerning the influence of the above mentioned determinants on economic growth and convergence. In the empirical part of the paper the real convergence process in the group of the 28 member states of the European Union in the period 2004-2015 is investigated and discussed. Next, panel growth regression model is performed in order to show the influence of the particular determinants on the pace of economic growth and real convergence process in the European Union.

Keywords: convergence, economic growth, "traditional" and "deep" determinants of economic growth, panel growth regression model

DOI: $10.15611 /$ aoe.2018.1.15

\section{INTRODUCTION}

The phenomenon of real convergence, which is the process of gradually reducing the development gap between countries, as measured by GDP per capita, has long been a subject of theoretical and empirical discussion. It can be assumed that this process is more likely to occur in integration groups (e.g. in the European Union), in other words, in a group of countries whose economies operate in a similar manner, i.e. on a similar level of economic and technological development, complementarity of economic structures, close geographic locations and institutional connections, ensuring the convergence of income to a common steady state (Bukowski (2011)).

\footnotetext{
* Department of International Business and Finance, K. Pulaski University of Technology and Humanities in Radom.
} 
Generally, the results of the majority of empirical studies on the convergence process in the European Union, also conducted by Polish economists (regardless of the method employed), confirms its existence (e.g. Growiec (2005); Schadler et al. (2006); Michałek et al. (2007); Liberda (2009); Rapacki (2009); Wolszczak-Derlacz (2009); Batóg (2010); Adamczyk and Łojewska (2011); Stawicka (2012); Walczak (2012); Staňisić (2012), Grzelak and Kujaczyńska (2013); Rapacki and Próchniak (2014)). The results of new empirical studies suggest, however, that negative demographic trends in the European Union may lead to the inversion of the current convergence tendencies and may cause a divergence process between the "new" and "old" EU countries (Matkowski et al. (2014)). Thus, the discussion on the convergence process in the EU has not finished yet.

According the neoclassical concept of Solow (1956) as factors determining the existence and the rate of convergence, traditional (shallow) economic growth factors have long been cited, i.e. the accumulation of labour force, the accumulation of capital and technology resources, the socalled Solow residual, resulting not from the accumulation of traditional production factors and affecting their productivity (Total Factor Productivity-TFP). Also human capital, mainly related to the level of education of the society, began to be included in the group of shallow growth factors (Mankiw et al. (1992)). Empirical studies over the traditional determinants of growth (Prescot (1997), Helpman (2004), Hulten (2000)) pointed to the significant influence of differences in Total Factor Productivity for the existence and rate of the convergence process within the studied groups of countries.

The search for more fundamental determinants of the convergence process has led to the emergence of the concept of the so-called "deep" determinants, to which Rodrick (2002) included geography (geographic location, natural resources, climate, etc.), institutions (the quality and efficiency of the functioning of institutions, law enforcement), and liberalisation (the degree of openness of economies, international trade intensity, mobility of capital and technology diffusion). Contemporary empirical studies seem to confirm this view, although there is still no consensus about the importance of individual determinants in shaping the convergence process.

Some empirical studies point to the important role of the geographical factor, whereby we can speak of two different approaches. The first views the geographical factor as directly affecting the rate of economic growth in the long run (Sachs (2000), Gallup et al. (1999), Brodzicki and Ciołek 
(2007)), while the second proves its indirect role in shaping the rate of convergence, mainly through the impact on the quality and shape of the institution (Engerman and Sokoloff (2000), Easterly and Levine (2003), Rodrik et al. (2004)) and the degree of liberalisation of the economy, mainly the intensity of trade and technology transfer (Fujita et al. (2001), Eaton and Kortum (2002), Keller (2001)).

The important role of institutions as a fundamental cause of differences in the level of GDP per capita was already pointed out in the 1970s by North and Thomas (1973), expressing the view that investment, the accumulation of human and physical capital, are somewhat equivalent to "growth" and a derivative of "the supreme cause" - the quality of institutions. Empirical studies conducted since the beginning of the 1990s (Knack (1996), Lane and Tornell (1996), Barro (1996), Hall and Jones (1999), Acemoglu et al. (2005), Rodrick (2002)), based both on the experience of postcolonial countries as well as more diverse groups of countries, indicate the significant influence of institutional determinants on shaping the real convergence process, even overshadowing the significance of other deep causes. In the literature of the subject (also Polish), the evidence for the significant impact of the institutional factor on the real convergence process in the EU can also be found (Kacprzyk (2012), Brodzicki and Ciołek (2007)). Moreover, the existence of the so-called "institutional convergence" between the "new" and "old" UE members was confirmed (Piątek (2014)).

The positive relationship between the degree of openness of the economy (trade liberalisation) and reducing the differences between countries were noticed by classical economy researchers (Smith, Mill) and structuralists (Nurkse, Myrdal), the proponents of the big push concept (Bartkowiak (2003)). This view became a common element in theorists' considerations only in the 1990s, e.g. Grossman and Helpman (1990, 1991), Barro and Sala-i-Martin (1997), Ben-David and Loewy (1998). More recent concepts indicated economic openness, understood more widely, as the liberalisation of capital and technology flows, as an important factor of the so-called catching-up growth of underdeveloped countries and the closely related convergence process (van de Klundert and Smulters (1998), Jones and Williams (1999), de la Fuente (2000), Sachs (2000), MłynarzewskaBorowiec (2014)).

Numerous empirical studies conducted using econometric methods and a variety of indices reflecting the degree of economic openness (Dollar (1992), Lee (1993), Sachs and Warner (1995), Edwards (1998), Vamvakidis (2002)), indicate the importance of the degree of economic openness on the rate of 
catching up with the developed countries by economically underdeveloped countries. The latest trends in research focus, on the one hand, on searching for the determinant which determines the impact of economic liberalisation on growth, mostly pointing to an increase in multi-factor productivity (Andersen and Babula (2008) and the government's economic policies (Chang et al. (2009)), and on the other hand, they question the importance of international exchange as such, focusing rather on the positive changes in its structure as a result of liberalisation (Hausman et al. (2005)).

The purpose of this paper is firstly to examine the existence and rate of the real convergence process in the group of the 28 member states of the European Union in the period from 2004 to 2015, and secondly, to determine the effect of traditional and deep determinants on the rate of economic growth of the EU member states and the convergence process between them. In accordance with the view that the geographical factor only indirectly affects economic growth through shaping the quality of institutions and the level of economic liberalisation, this is not taken into account in the analysis. In the paper, the hypothesis is verified that the "new" EU member states accelerate the real convergence process in the EU, and hence the determinants of their economic growth, play a key role in shaping the convergence process in the entire integration group. In the study, econometric methods are used, in particular the cross-sectional and panel growth regression models.

\section{THE PRELIMINARY STUDY OF THE REAL CONVERGENCE PROCESS IN THE EUROPEAN UNION IN 2004-2015}

\subsection{Methodology and data}

The studies on the real convergence process are usually concentrated on the verification of $\beta$-convergence (absolute and conditional) and $\sigma$ convergence hypotheses. Studies on the existence of $\beta$-convergence can be conducted with the use of averaged data for the entire period or panel data. Taking into account the most traditional method based on averaged data, one should be aware that a limited number of observations influence the statistical credibility of the obtained results. However, from the economic point of view, the above mentioned approach seems to be appropriate, because it gives an opportunity to investigate the relation between initial conditions of economies and their long-term growth processes. In this paper 
the above method is used to pre-test the absolute $\beta$-convergence hypothesis for the European Union.

In the study based on averaged data, the easiest way to test the hypothesis of absolute $\beta$-convergence process is estimating the structural parameters of the following equation provided by Sala-i-Martin (1996):

$$
\frac{1}{T} \ln \left(\frac{Y_{i, T}}{Y_{i, 0}}\right)=\alpha_{0}+\alpha_{1} \ln Y_{i, 0}+\varepsilon_{i, T},
$$

where:

$\alpha_{1}=-\left(1-e^{-\beta T}\right) / T$,

$Y_{i, t}-$ GDP per capita of country $i$ in period $t$.

The left side of the equation represents the average growth rate of GDP per capita of country $i$ between the period $T$ and the base period 0 . The explanatory variable is the logarithm of the initial level of GDP per capita of country $i$. The negative value of the parameter $\alpha_{i}$ means the occurrence of convergence, whose rate is reflected by the coefficient $\beta$ defined by the following formula:

$$
\beta=-\frac{1}{T} \ln \left(1+\alpha_{1} T\right) .
$$

The higher the coefficient $\beta$ value (between 0 and 1), the higher the convergence rate.

Due to the fact that the $\beta$-convergence can be treated as one, but not the only determinant of the convergence process manifested by a reduction in disparities in GDP per capita of a certain group of countries, i.e. the $\sigma$ convergence (Friedman (1992), Quah (1993)), it appears reasonable to investigate the existence of this type of convergence in the analysed group of countries. The popular method to test the $\sigma$-convergence hypothesis is to compare the variance of GDP per capita in two extreme periods (the first and the last one). $\sigma$-convergence exists, if the variance in the last period is significantly lower than the initial variance, and the hypothesis of equality of the two variances can be rejected. However, this approach, introduced by Lichtenberg (1994) and then improved by Carre and Klomp (1997), ignores changes of variance occurring between the initial and final period. In other words, one cannot assess whether a decrease in diversity in the analysed group of countries has a permanent nature or not. A relatively simple way to verify it is to estimate a trend line for the difference levels of GDP per capita 
between countries (e.g. measured by the standard deviation of the logarithms of GDP per capita):

$$
s d\left(\ln Y_{t}\right)=\lambda_{0}+\lambda_{1} t+\omega_{t} .
$$

A negative and statistically significant $\lambda_{1}$ parameter (with the value ranging from -1 to 0 ) indicates the occurrence of $\sigma$ convergence.

The mentioned equations (1) and (3) were used to conduct a preliminary study of absolute $\beta$ and $\sigma$-convergence process in the group of 28 European Union member states. The dataset used in the survey included variables observed at annual intervals in the period 2004-2015. Data on GDP per capita of the member states was expressed in Purchasing Power Parity (PPP) and obtained from the World Bank Development Indicators Database (WDI), 2016 (data in international dollars). The survey was conducted not only for the entire group of 28 countries (EU-28), but also for two sub-groups: the group of 15 "old" members (EU-15: Belgium, Denmark, Germany, Ireland, Greece, Spain, France, Italy, Luxembourg, the Netherlands, Austria, Portugal, Finland, Sweden, the United Kingdom) and the group of 13 "less developed" countries (EU-13: Bulgaria, the Czech Republic, Estonia, Cyprus, Latvia, Lithuania, Hungary, Malta, Poland, Romania, Slovenia, the Slovak Republic and Croatia), that joined the EU in 2004 and later.

\subsection{Absolute $\beta$-convergence in the $\mathbf{E U}$}

The estimation results of equation (1) using averaged data for the mentioned groups of countries (EU-28, EU-13 and EU-15) are included in Table 1. The Student's t-test was used to assess the significance of the parameters, and the coefficient of determination $\left(R^{2}\right)$ - to measure the degree of compliance of the models. In addition, White's test for heteroscedasticity and the Jarque-Bera test for normality were conducted. The results were satisfactory and confirmed that the OLS estimator was efficient and unbiased.

The obtained results indicate the presence of the absolute $\beta$-convergence process in the EU-28 group in the analysed period. The negative value of the statistically significant structural parameter $\alpha_{1}$ of equation (1) indicates a negative correlation between the initial level of GDP per capita (in 2004) and the economic growth rate in the period of 2004-2015. The speed of the convergence process, calculated with the use of formula (2), amounts to 0.2632 . This means that the countries with lower GDP per capita (EU-13 group) approached the level of prosperity of the richer ones (mainly countries from the EU-15 group) at a rate of approximately $2.6 \%$ per year. 
Table 1

Estimation results of the cross-sectional model (1) describing absolute $\beta$-convergence process in the European Union in the period 2004-2015; OLS method of estimation

\begin{tabular}{|c|c|c|c|}
\hline Coefficient / model diagnostics & EU-28 & EU-13 & EU-15 \\
\hline$\alpha_{0}$ & $\begin{array}{c}0.25697 \\
(0.04191)^{* * *}\end{array}$ & $\begin{array}{c}0.37607 \\
(0.08940)^{* * *}\end{array}$ & $\begin{array}{l}-0.05244 \\
(0.07685) \\
\end{array}$ \\
\hline$\alpha_{1}$ & $\begin{array}{c}-0.02285 \\
(0.00422)^{* * *}\end{array}$ & $\begin{array}{c}-0.035275 \\
(0.00940)^{* * *}\end{array}$ & $\begin{array}{c}0.00715 \\
(0.00747) \\
\end{array}$ \\
\hline$\beta$-convergence & yes & yes & no \\
\hline$\beta$ coefficient & 0.02632 & 0.04464 & - \\
\hline Number of observations & 28 & 13 & 15 \\
\hline Model diagnostics: & & & \\
\hline$R^{2}$ & 0.63044 & 0.76182 & 0.56581 \\
\hline Adjusted $R^{2}$ & 0.62238 & 0.72198 & 0.53764 \\
\hline $\begin{array}{l}\text { White's test }{ }^{1} \text { : } \\
\text { test statistics } \\
\text { [p value] }\end{array}$ & $\begin{array}{l}0.00785 \\
{[0.9961]}\end{array}$ & $\begin{array}{l}0.02073 \\
{[0.9899]}\end{array}$ & $\begin{array}{l}0.23287 \\
{[0.8901]}\end{array}$ \\
\hline $\begin{array}{l}\text { JB normality test }{ }^{2} \text { : } \\
\text { test statistics } \\
\text { [p value] }\end{array}$ & $\begin{array}{l}0.2519 \\
{[0.8817]}\end{array}$ & $\begin{array}{l}1.5625 \\
{[0.4578]}\end{array}$ & $\begin{array}{l}0.2519 \\
{[0.8817]}\end{array}$ \\
\hline
\end{tabular}

Note:

The numbers in brackets denote the value of standard error. ***means significance at $1 \%$.

${ }^{1}$ White's test: null hypothesis $\mathrm{H}_{0}$ : variance of error term is constant across observations (homoscedasticity).

${ }^{2}$ JB normality test: null hypothesis $\mathrm{H}_{0}$ : normal distribution.

Source: own calculations using GRETL.

The $\alpha_{1}$ coefficient obtained for the EU-13 group is also statistically significant and its negative sign stands for the existence of the convergence process between the "new" EU members. In the analysed period, the speed of the catching-up process between them was relatively higher and amounted to about $4.5 \%$ per annum.

According to the results included in Table $1, \alpha_{1}$ parameter obtained for the EU-15 group is positive and statistically insignificant. This means that in the analysed period the divergence process between the "old" EU members existed.

In the light of the obtained results it can be stated that the catching-up process took place mainly within the EU-13 group and between them and the countries from the EU-15 group. It can therefore be pre-assumed that the socalled "new" member states had a crucial influence on the convergence process in the EU and its dynamics. 


\section{3. $\sigma$-convergence in the $\mathbf{E U}$}

The existence of $\sigma$-convergence was tested by estimating the structural parameters of equation (3), defining the variability in time (2004-2015) of standard deviation of the GDP per capita logarithms in the three groups of countries. In all the models the results of the Student's t test confirmed the significance of the parameters at a $1 \%$ level. The high value of the determination coefficients of about $90 \%$ indicated a significant degree of compliance of the models. The White's tests and the Jarque-Bera tests were also satisfactory. The estimation results of the trend lines are presented in Table 2.

Table 2

Estimation results of the trend line (3) describing $\sigma$-convergence in the European Union in the period 2004-2015; OLS method of estimation

\begin{tabular}{|c|c|c|c|}
\hline Coefficient / model diagnostics & EU-28 & EU-13 & EU-15 \\
\hline$\gamma_{0}$ & $\begin{array}{c}0.48209 \\
(0.00721)^{* * *}\end{array}$ & $\begin{array}{c}0.32868 \\
(0.00546)^{* * *}\end{array}$ & $\begin{array}{c}0.25149 \\
(0.00380)^{* * *}\end{array}$ \\
\hline$\gamma_{1}$ & $\begin{array}{c}-0.009513 \\
(0.000979)^{* * *}\end{array}$ & $\begin{array}{c}-0.00824 \\
(0.00074)^{* * *}\end{array}$ & $\begin{array}{c}0.00244 \\
(0.00052)^{* * *}\end{array}$ \\
\hline$\sigma$ convergence & yes & yes & no \\
\hline Number of observations & 12 & 12 & 12 \\
\hline \multicolumn{4}{|l|}{ Model diagnostics: } \\
\hline$R^{2}$ & 0.9041 & 0.9251 & 0.6907 \\
\hline Adjusted $R^{2}$ & 0.8946 & 0.9176 & 0.6598 \\
\hline $\begin{array}{l}\text { White's test }{ }^{1} \text { : } \\
\text { test statistics } \\
\text { [p value] }\end{array}$ & $\begin{array}{l}1.3224 \\
{[0.5162]}\end{array}$ & $\begin{array}{l}2.3234 \\
{[0.3130]}\end{array}$ & $\begin{array}{l}3.3795 \\
{[0.1846]}\end{array}$ \\
\hline $\begin{array}{l}\text { J-B normality test }{ }^{2} \text { : } \\
\text { test statistics } \\
\text { [p value] }\end{array}$ & $\begin{array}{l}1.7288 \\
{[0.4213]}\end{array}$ & $\begin{array}{l}0.1865 \\
{[0.9111]}\end{array}$ & $\begin{array}{l}0,9080 \\
{[0.6351]}\end{array}$ \\
\hline
\end{tabular}

Note:

The numbers in brackets denote the value of standard error. ***means significance at $1 \%$.

${ }^{1}$ White's test: null hypothesis $\mathrm{H}_{0}$ : variance of error term is constant across observations (homoscedasticity).

${ }^{2} \mathrm{JB}$ normality test: null hypothesis $\mathrm{H}_{0}$ : normal distribution.

Source: own calculations using GRETL. 
In the light of the obtained results for the period of 2004-2015, the EU-28 group as well as the EU-13 group showed $\sigma$-convergence process, i.e. the degree of differentiation of GDP per capita in these groups decreased with time. This is shown by the negative value of the structural parameters $\gamma_{1}$ amounting to -0.0095 and -0.0082 respectively. The values of the estimated parameters suggest, however, that the intensity of $\sigma$-convergence process in the both groups was rather low.

The estimation results of equation (3) for the countries from the EU-15 group indicate the absence of $\sigma$-convergence process. The positive and statistically significant $\gamma_{1}$ parameter stands for the presence of divergence tendencies in that group.

In light of the above results, the assumption that the EU-13 group has a significant impact on the convergence process in the entire EU seems to be still valid. Therefore it appears reasonable to examine which factors (traditional and deep) affect the growth and convergence process in that group of countries.

\section{EMPIRICAL ANALYSIS OF THE IMPACT OF TRADITIONAL AND DEEP DETERMINANTS ON THE CONVERGENCE IN THE EUROPEAN UNION IN THE PERIOD 2004-2015}

\subsection{Methodology and data}

The impact of the particular factors affecting the growth and convergence process in the EU-13 group in the period from 2004 to 2015 was investigated with the use of panel growth regression models. In contrast to cross-sectional data models, in panel data models a larger number of observations (and degrees of freedom) can be taken into account. Moreover, an important feature of panel models' structure is that they distinguish a constant-in-time and object-specific group effects. Thus, the panel data approach seems to be more solid. Therefore the following general form of panel model was used to test for the conditional $\beta$ convergence process and its determinants in the EU-13 group:

$$
\ln \left(\frac{Y_{i, t}}{Y_{i, t-1}}\right)=\alpha-\beta \ln \left(Y_{i, t-1}\right)+\gamma X_{i, t}+\vartheta_{t}+\theta_{i}+\varepsilon_{i, t},(4)
$$

where: $Y_{i, t}-$ GDP per capita of country $i$ in period $t ; \ln \left(Y_{i, t} / Y_{i, t-1}\right)-$ GDP per capita growth rate, $X_{i, t}-$ a vector of the logarithms of variables representing 
traditional and deep determinants of growth and convergence; $\vartheta_{t}-$ time-specific effects; $\theta_{i}$ - country-specific effects; $\varepsilon_{i, t}$-random term.

In equation (4) parameter $\beta$ can be described by the following formula:

$$
\beta=\frac{1-e^{-\beta^{*} T}}{T}
$$

where: $T$ - the number of years $(t=1, \ldots ., T) ; \beta^{*}-$ the speed of the conditional $\beta$-convergence process.

Equation (4) can be transformed to a dynamic panel data model by adding $\ln \left(Y_{i, t-1}\right)$ to both sides, which gives:

$$
\ln \left(Y_{i, t}\right)=\alpha+(1-\beta) \ln \left(Y_{i, t-1}\right)+\gamma X_{i, t}+\vartheta_{t}+\theta_{i}+\varepsilon_{i, t} .
$$

The equation has the following properties: for $i=1, \ldots, N$ and $t=1, \ldots, T: E\left(\varepsilon_{i, t}\right)=0 ; E\left(\varepsilon_{i, t} \varepsilon_{i, s}\right)=0$ for $t \neq s ; E\left(\varepsilon_{i, t} \varepsilon_{i, t}\right)=\delta_{\varepsilon}^{2}=$ const ; $E\left(\varepsilon_{i, t} \theta_{i}\right)=0 ; E\left(\varepsilon_{i, t} \vartheta_{t}\right)=0 . \theta_{i}$ are assumed to be random effects and $\vartheta_{t}$ - fixed effects.

The selection of the elements of vector $X_{i}$ was carried out considering both the traditional neoclassical Solow's approach and the research on the deep determinants of economic growth discussed in the first part of the paper. A dozen or so models were estimated, having the alternative measures and number of variables reflecting traditional and deep determinants of economic growth. Finally, four versions of model (5) (from basic to the most extended) were estimated with the selected explanatory variables listed below:

a) $n_{i, t}+g+\delta$ - population growth $\left(n_{i, t}\right)$ increased by 0.05 (where 0.05 represents the sum of technical development rate common for all countries $g$ and depreciation rate $\delta$ ); data obtained from the IMF World Economic Outlook Database (2016);

b) $s_{i, t-1}$ - investment rate, reflecting the accumulation of physical capital, measured as gross fixed capital formation in relation to GDP in the previous year $(t-1)$, obtained from the World Bank WDI Database (2016);

c) $H U M_{i, t}$ - the variable reflecting the accumulation of human capital expressed as the indicator of adult education level (tertiary) calculated as the 
percentage of people having completed the highest level of education in the age group of 25-64, obtained from the OECD Database (2016);

d) $I N S T_{i, t}$ - the variable describing the quality of institutions, expressed as the indicator of rule of law, calculated by the World Bank (World Bank Governance Indicators database 2016);

e) $O P E N_{i, t}$ - the variable showing the degree of economic openness of country $i$ in period $t$; the indicator was calculated as the value of international trade (exports and imports) in relation to GDP, data obtained from the World Bank WDI Database (2016);

f) $H_{-} T-F L_{i, t-1}$ - the variable showing the degree of economic openness of country $i$ by the intensity of technology flows in the previous year $t-1$, calculated as the share of exports and imports of high-tech goods in total trade; calculated using data obtained from the World Bank WDI Database (2016);

g) $C A P_{-} F L_{i, t-1}-$ the variable reflecting the degree of economic openness by the intensity of capital flows in country $i$ in period $t-1$, calculated as the ratio of the sum of FDI inflows and outflows to GDP, calculated on the basis of data obtained from the World Investment Report 2016 (UNCTAD).

All the variables were transformed into the form of deviations from the period mean (by subtracting the period mean from each of the series). In this way the time-specific effects $\left(\vartheta_{t}\right)$ could have been eliminated from the models.

Models (5) were estimated by the Blundell-Bond system GMM estimator. The SGMM estimator is recommended for estimating conditional convergence models such as model (5). It offers better results when the time dimension is short, autoregressive parameter $(1-\beta)$ approaches 1 , and when the variance of the individual effects $\left(\theta_{i}\right)$ is high (Baltagi (2005)). In the first difference equations, the lagged levels of variables $\ln \left(Y_{i, t}\right)$, $\ln \left(n_{i, t}+g+\delta\right)$ and $\ln \left(s_{i, t-1}\right)$ were used as instruments. Additional regressors, considered as exogenous, were used as their own instruments. In the level equations, the additional instruments were: $\Delta \ln \left(Y_{i, t-1}\right)$, $\Delta \ln \left(n_{i, t-1}+g+\delta\right)$ and $\Delta \ln \left(s_{i, t-2}\right)$. The rest of the regressors were used as their own instruments. It was assumed that the instruments were valid when $E\left(\theta_{i} \Delta \ln \left(Y_{i, 2}\right)\right)=0$ for $i=1, \ldots, N$.

The models were evaluated with the Arellano-Bond test for autocorrelation (the existence of autocorrelation of an order higher than 
1 means that the instruments are not valid). As the robust variance estimators were calculated, the Sargan test for over-identification could not be applied (the empirical distribution of the Sargan test statistics was not known). As the results obtained using one-step estimation were not satisfactory, the results obtained in the second-step of estimation were presented.

\subsection{Traditional and deep determinants of the convergence process in the $\mathrm{EU}-13$ group - results}

The estimation results of the particular variants of model (5) are presented in Table 3. The first estimated regression corresponds to the traditional, neoclassical Solow's approach (5a). The second regression (5b) is the enlarged version of the above model containing a variable reflecting the accumulation of human capital $(H U M)$. Model $5 \mathrm{c}$ is a conditional convergence model that incorporates variables describing the openness of economy (OPEN) and the quality of institutions (INST). In model $5 \mathrm{~d}$, two additional variables describing the degree of openness of economy are included $\left(H_{-} T_{-} F L\right.$ and CAP_FL).

The results of the Arellano-Bond test for autocorrelation indicate that the instruments used in the estimation procedure are valid. This statement concerns all the variants of models presented in columns 2-5 in Table 3.

In each model the autoregressive parameter $(1-\beta)$ turned out to be statistically significant with the value approaching 1 . The estimated value of this parameter was used to calculate the convergence rate in the analysed group of countries. It was calculated with the use of the following formula:

$$
\beta^{*}=-\ln (1-\beta T) / T .
$$

The estimation results of other structural parameters of the basic model (5a) show the positive impact of accumulation of labour force and technological development on the economic growth of countries in the EU13 group. However, the parameter for the variable representing the investment rate turned out to be statistically insignificant. Assuming that the analysed countries had a similar rate of population growth and technological progress, the rate of convergence process between them would amount to about 3.3 per cent per year. 
Table 3

Estimation results of the panel model (5) describing determinants of the convergence process in the EU-13 group in the period 2004-2015; robust standard errors; SGMM (two-step) method of estimation

\begin{tabular}{|c|c|c|c|c|}
\hline Variables & (5a) & $(5 b)$ & $(5 c)$ & $(5 d)$ \\
\hline $\ln \left(G D P_{i, t-1}\right)$ & \begin{tabular}{|l|}
0.9738 \\
$(0.0177)^{* * *}$ \\
\end{tabular} & $\begin{array}{l}0.9708 \\
(0.0142)^{* * *}\end{array}$ & $\begin{array}{l}0.95989 \\
(0.0251)^{* * *}\end{array}$ & $\begin{array}{l}0.95365 \\
(0.0393)^{* * *}\end{array}$ \\
\hline $\ln \left(n_{i, t}+g+\delta\right)$ & \begin{tabular}{|l|}
0.0577 \\
$(0.0318)^{*}$ \\
\end{tabular} & $\begin{array}{l}0.0657 \\
(0.0223) * * *\end{array}$ & $\begin{array}{l}0.0144 \\
(0.0278) \\
\end{array}$ & $\begin{array}{l}0.0583 \\
(0.0439) \\
\end{array}$ \\
\hline $\ln \left(s_{i, t-1}\right)$ & $\begin{array}{l}-0.0160 \\
(0.0164) \\
\end{array}$ & $\begin{array}{l}0.0045 \\
(0.0144) \\
\end{array}$ & $\begin{array}{l}0.0216 \\
(0.0231) \\
\end{array}$ & $\begin{array}{l}0.0069 \\
(0.0207) \\
\end{array}$ \\
\hline $\ln \left(H U M_{i, t}\right)$ & & $\begin{array}{l}0.2397 \\
(0.0334)^{* * *}\end{array}$ & $\begin{array}{l}0.0610 \\
(0.0299)^{* *}\end{array}$ & $\begin{array}{l}0.1558 \\
(0.0580)^{* * *}\end{array}$ \\
\hline $\ln \left(I N S T_{i, t}\right)$ & & & $\begin{array}{l}0.3708 \\
(0.0480)^{* * *}\end{array}$ & $\begin{array}{l}0.4319 \\
(0.0785)^{* * *}\end{array}$ \\
\hline $\ln \left(O P E N_{i, t}\right)$ & & & $\begin{array}{l}0.0337 \\
(0.0161)^{* *}\end{array}$ & $\begin{array}{l}0.0369 \\
(0.0104)^{* * *}\end{array}$ \\
\hline $\ln \left(H_{-} T_{-} F L_{i, t-1}\right)$ & & & & $\begin{array}{l}-0.0193 \\
(0.0171) \\
\end{array}$ \\
\hline $\ln \left(C A P_{-} F L_{i, t-1}\right)$ & & & & $\begin{array}{l}0.0102 \\
(0.0038) * * *\end{array}$ \\
\hline$\beta$-convergence & yes & yes & yes & yes \\
\hline convergence rate $\beta^{*}$ & 0.0315 & 0.0360 & 0.0547 & 0.0677 \\
\hline Number of obs. & 143 & 143 & 143 & 143 \\
\hline $\begin{array}{l}\text { Arellano-Bond AR } \\
\text { test: }\end{array}$ & & & & \\
\hline $\begin{array}{l}\operatorname{AR}(1) \\
\text { test statistics } \\
\text { [p value] } \\
\text { AR( }(2) \\
\text { test statistics } \\
\text { [p value] }\end{array}$ & $\begin{array}{l}-1.8550 \\
{[0.0636]} \\
0.2628[0.3927]\end{array}$ & $\begin{array}{l}-1.9370 \\
{[0.0527]} \\
0.2949 \\
{[0.4681]}\end{array}$ & $\begin{array}{l}-2.0491 \\
{[0.0405]} \\
0.2871 \\
{[0.3741]} \\
\end{array}$ & $\begin{array}{l}-1.8954 \\
{[0.0580]} \\
0.1926 \\
{[0.7472]}\end{array}$ \\
\hline
\end{tabular}

Note: $* * * / * * / *$ means the significance level of $1 \% / 5 \% / 10 \%$. Standard errors in parentheses

Source: own calculations using GRETL.

In the extended version of the previous model (model 5b), all the structural parameters were estimated as positive, but the parameter for the variable representing the investment rate was statistically insignificant. Among the traditional determinants, human capital resources turned out to have the greatest impact on GDP per capita growth in the EU-13 group. The value of the estimated parameter for the $H U M$ variable amounted to 0.24 . Assuming that countries in the analysed group were additionally similar in terms of the human capital resources, the average annual convergence rate would be higher by about 0.5 percentage point. 
The estimates of model $5 \mathrm{c}$ indicate that not only human capital, but also deep growth factors like the degree of openness of economies and, above all, the quality of institutional adjustments, had a significant and positive influence on the rate of economic growth in the EU-13 group. The relevant structural parameters were statistically significant, and their values amounted to $0.06,0.03$ and 0.37 , respectively. The similarity of the countries in these areas would result in a much higher convergence rate of about 5.5 percent per year on average.

The estimation results of the last conditional convergence model (5d) also point at the highly qualified labour force and institutions as the key factors of economic growth processes in the analysed group of countries. The values of the estimated parameters amounted to about 0.16 and 0.43 respectively. The positive value $(0.01)$ of the statistically significant parameter for the variable CAP_FL stands for the positive but very small impact of FDI flows on GDP per capita growth. According to the obtained results, traditional determinants (accumulation of labour force and physical capital), as well as the level of countries' involvement in international technology flows, were found to be irrelevant in shaping convergence process in the EU-13 group. If the mentioned countries showed a high similarity in terms of human capital resources, quality of institutions and their openness to foreign investment, the convergence rate between them would amount to about $7 \%$ per annum.

\section{CONCLUSIONS}

The paper provides evidence for the presence of $\sigma$-convergence process between European Union countries in the period 2004-2015. The preliminary analysis conducted for the EU-28 group confirm that the process of reducing development disparities was mainly connected with the catching-up phenomenon ( $\beta$-convergence). The speed of $\beta$-convergence process was much higher between the 13 "new" member states than in the entire group. Interestingly, the $\beta$-convergence process between the most developed "old" EU members did not exist. Thus, it can be concluded that in the analysed period the EU-13 members were catching up with the richer countries from that group as well as from the EU-15 group. This seems to confirm the hypothesis that the "new" EU member states accelerated the real convergence process in the EU, and hence determinants of their economic growth, played an important role in shaping the convergence process in the entire integration group. 
The research based on panel data models confirmed the presence of $\beta$ convergence in the EU-13 group and pointed out the causes of that process. Among the traditional factors, the accumulation of labour force, and mainly the accumulation of human capital, had a significant impact on economic growth in the EU-13 group. The similarity of countries in terms of a highly skilled labour force resulted in a higher convergence rate (by about 0.5 percentage point).

Considering deep determinants, GDP per capita growth in these countries resulted primarily from the improvement of the quality of institutions, a positive role was also played by the gradual liberalisation of trade and technology transfer. In light of the obtained results, if the analysed countries showed a significant similarity in terms of deep determinants (especially in terms of institutional functioning), the convergence rate between them could be higher by 2-3 percentage points per year.

Considering the above insights, it can be stated that the greatest influence on the convergence rate in the EU was exerted by positive institutional changes related to the transparency of law and the efficiency of its application in society. This is consistent with the results of other economists' research (cited in the first part of the paper), highlighting the importance of the institutional factor as the "supreme cause", overshadowing the significance of other deep causes. This is also in line with the concept of institutional convergence in the EU. The results of the study indicate that the countries' efforts to pursue a path towards the similar, high legal and institutional standards which may accelerate the convergence process between them.

These positive institutional changes in the EU-13 group are undoubtedly largely connected with the gradual integration with the wealthier EU member states and the implementation of the necessary and system changes "forced" by the membership. The appropriate changes in this area, in combination with the progressive liberalization of economic exchange and the investment in human capital (investment in education, human skills, lifelong learning, $R \& D$ sector), may significantly reduce development disparities in the EU in the future.

The conducted research should be regarded as a preliminary study of the convergence determinants in the integration groups. In further research it would be advisable to use more complex measures of growth determinants (to construct the composite indexes of quality of institutions, human capital resources etc.). Additionally, it is reasonable to conduct similar surveys in relation to other integration groups functioning in the modern world economy. 


\section{REFERENCES}

Adamczyk-Łojewska, G., Problemy konwergencji i dywergencji ekonomicznej na przykładzie krajów Unii Europejskiej, w tym Polski [Problems of Convergence and Divergence on the Example of EU Countries, Including Poland] „Prace Naukowe Uniwersytetu Ekonomicznego we Wrocławiu. Ekonomia”, No 211, pp. 57-76, 2011.

Acemoglu, D., Johnson, S., Robinson, J. A., The Rise of Europe: Atlantic Trade, Institutional Change and Economic Growth, "American Economic Review", Vol. 95, no 3, pp. 546-579, 2005.

Andersen, L., Babula, R., The Link between Openness and Long-run Economic Growth, "Journal of International Commerce and Economics", pp. 13-15, 2008.

Baltagi, B. H., Econometric Analysis of Panel Data. John Wiley\&Sons Ltd., New York, 2005.

Barro, R., Sala-i-Martin, X., Technological Diffusion, Convergence, and Growth, "Journal of Economic Growth, Vol. 2(1), pp. 1-26, 1997.

Barro, R., Institutions and Growth: An Introductory Essay, "Journal of Economic Growth", Vol. 1, No 1, pp. 145-148, 1996.

Bartkowiak, R., Historia myśli ekonomicznej [History of Economic Thought]. PWE, Warsaw, 2003.

Batóg, J., Konwergencja dochodowa w krajach Unii Europejskiej. Analiza ekonometryczna [Income Convergence in European Union Member States: Econometric Analysis]. „Rozprawy i studia”, No 780, 2010.

Ben-David, D., Loewy, M. B., Free Trade, Growth and Convergence, "Journal of Economic Growth", No 3, pp. 143-170, 1998.

Brodzicki, T., Ciołek, D., Glębokie determinanty wzrostu gospodarczego- weryfikacja empiryczna $z$ wykorzystaniem metod estymacji panelowych [Deep Determinants of Economic Growth- Empirical Verification with Panel Data Estimations], "Analizy i Opracowania KEIE UG”, No 1. pp.6-42, 2007.

Bukowski, S. I., Unia ekonomiczna $i$ monetarna a różnice $w$ rozwoju regionów gospodarczych - ujecie teoretyczne [Economic and Monetary Union and Development Disparities of the Economic Regions - Theoretical Aspects [in:] Bukowski, S. I. (ed.) Polityka kohezji i konwergencja gospodarcza regionów Polski oraz krajów Unii Europejskiej. Wybrane zagadnienia [Cohesion Policy and Economic Convergence of the Polish Regions and Member States of the European Union . Selected Issues], pp. 11-29, Difin, Warsaw, 2011.

Carree, M., Klomp, L., Testing the Convergence Hypothesis: A Comment, "Review of Economics and Statistics", Vol. 79, No 4, pp. 683-686, 1997.

Chang, R., Kaltani, L., Loayza, N. V., Openness Can Be Good for Growth: The Role of Policy Complementarities, "Journal of Development Economics", No 90, pp. 36-46, 2009.

Dollar, D., Outward-oriented Developing Economies Really Do Grow More Rapidly: Evidence from 95 LDCs, 1976-1985, "Economic Development and Cultural Change", Vol. 40, pp. 523-544, 1992.

Easterly, W., Levine, R., Tropics, Germs, and Crops: How Endowments Influence Economic Development, "Journal of Monetary Economics", Vol. 50, No 1, pp. 3-39, 2003. 
Eaton, J., Kortum, S., Technology, Geography and Trade, "Econometrica”, Vol. 70, No 5, pp. 4-51, 2002.

Edwards, S., Openness, Productivity and Growth: What We Really Know?, "The Economic Journal", Vol. 108, pp. 384-396, 1998.

Engerman, S. L., Sokoloff, K. L., History Lessons: Institutions, Factor Endowments, and Path of Development in the World, "Journal of Economic Perspectives", Vol. 14, No 3, pp. 217-232, 2000.

Fuente, A., Convergence across Countries and Regions: Theory and Empirics, "EIB Papers/BEI", Vol. 2, No 5, pp. 5-10, 2000.

Fujita, M., Krugman, P. R, Venables, A. J., The Spatial Economy: Cities, Regions and International Trade, MIT Press, 2001.

Gallup, J. L., Sachs, J. D., Mellinger, A. D., Geography and Economic Development, "CID Working Paper", No. 1, pp. 7-34, 1999.

Grossman, G., Helpman, E., Innovation and Growth in the Global Economy, MIT Press, Cambridge, 1991.

Grossman, G.,Helpman, E., Trade, Knowledge Spillovers and Growth, "NBER Working Papers", No 3485, pp.7-12, 1990.

Growiec, J., Dynamika konwergencji Polski z Unia Europejska [Dynamism of Poland's Convergence with EU] , „Gospodarka Narodowa”, No 5-6,pp. 101-118, 2005.

Grzelak, A., Kujaczyńska, M., Real Convergence of the European Union Member States Evaluation Attempt, "Management", No 17, pp. 394-405, 2013.

Hall, R. E., Jones, C. I., Why Do Some Countries Produce So Much More Output Per Worker Than Others?, "The Quarterly Journal of Economics", Vol. 114, No 1, pp. 83-116, 1999.

Hausmann, R., Hwang, J., Rodrick, D., What You Export Matters, “Journal of Economic Growth", Vol. 12, pp. 5-18, 2005.

Helpman, E., The Mystery of Economic Growth. Harvard University Press, Cambridge, 2004.

Hulten, C., Total Factor Productivity: A Short Biography, "NBER Working Papers", No 7471, pp. 26-63, 2000.

Jones, C., Williams, J. C., Too Much of a Good Thing? The Economics of Investment in R\&D, "NBER Working Papers", No 7283, pp. 1-21, 1999.

Kacprzyk, A., Instytucjonalne determinanty wzrostu gospodarczego w Unii Europejskiejanaliza panelowa[Institutional Determinants of Economic Growth in the European Union - Panel Analysis], [in:] Misztal, P., Rakowski, W.(eds.): Przyszłość integracji europejskiej. Uwarunkowania rozwoju gospodarczego Unii Europejskiej [The Future of European Integration. Determinants of Development in the European Union], pp. 53-64. CeDeWu, Warsaw, 2012.

Keller, W., International Technology Diffusion, "NBER Working Papers”, No 8573, pp. 2426, 2001.

Klundert, T., Smulters, S., Capital Mobility and Catching Up in the Two-Country, Two-Sector Model of Endogenous Growth, “Tilburg University Working Paper”, No 13, pp.1-31, 1998.

Knack, S., Institutions and the Convergence Hypothesis: The Cross-National Evidence, "Public Choice", Vol. 87, No. 3.4, pp. 207-228, 1996. 
Lane, P. R., Tornell, A., Power, Growth and the Voracity Effect, "Journal of Economic Growth", No 1, pp. 213-241, 1996.

Lee, J-W, International Trade, Distortions, and Long-run Growth, "IMF Staff Papers" Vol.40(2), pp. 299-328, 1993.

Liberda, Z. B. (ed.), Konwergencja gospodarcza Polski [Economic Convergence of Poland]. PTE, Warsaw, 2009.

Lichtenberg, F. R., Testing the Convergence Hypothesis, "The Review of Economics and Statistics", Vol. 76, No. 3, pp. 576-79, 1994.

Mankiw, N. G., Romer, D., Weil, D. N., A Contribution to the Empirics of Economic Growth, "Quarterly Journal of Economics", Vol. 107, pp. 407-437, 1992.

Matkowski, Z., Próchniak, M., Rapacki, R., Scenariusze realnej konwergencji $w$ Unii Europejskiej - kraje Europy Środkowo-Wschodniej a UE15 [Scenarios of the Real Convergence in the European Union - Central and Eastern Europe Countries and the EU15] [in:] Gorynia, M., Rudolf, S. (eds.) Polska w Unii Europejskiej i globalnej gospodarce [Poland in the European Union and Global Economy], pp. 201-222. PTE, Warsaw, 2014.

Michałek, J. J., Siwiński, W., Socha, M. (eds.), Polska w Unii Europejskiej - dynamika konwergencji ekonomicznej [Poland in the EU - The Dynamics of Economic Convergence]. PWN, Warsaw, 2007.

Młynarzewska-Borowiec, I., Otwartość gospodarek a zjawisko konwergencji realnej na przykładzie krajów członkowskich Unii Europejskiej [Openness of Economies vs Phenomenon of Real Convergence on the Example of Member States of EU], „Współczesne problemy ekonomiczne: globalizacja, liberalizacja, etyka. Zeszyty Naukowe Uniwersytetu Szczecińskiego", No 800, pp. 87-98, 2014.

North, D. C., Thomas, R., The Rise of the Western World: A New Economic History. Cambridge University Press, Cambridge, 1973.

Prescot, C., Needed: The Theory of Total Factor Productivity, "Research Department Staff Report 242", Federal Reserve Bank of Minneapolis, pp. 10-34, 1997.

Quah, D. T., Galton's Fallacy and Tests of the Convergence Hypothesis, "Scandinavian Journal of Economics",Vol. 95, No 3, pp. 427-43, 1993.

Piątek, D., Konwergencja instytucjonalna w krajach transformujacych się [Institutional Convergence in Transition Countries], ,Studia i Prace Wydziału Nauk Ekonomicznych i Zarządzania”, No 35, pp. 475-489, 2014.

Rapacki, R., Próchniak, M., Wpływ członkostwa w Unii Europejskiej na wzrost gospodarczy $i$ realna konwergencje krajów Europy Środkowo-Wschodniej [The Impact of EU Membership on Economic Growth and Real Convergence of the Central and Eastern European Countries], „Ekonomia”, No 39, pp. 87-12, 2014.

Rapacki, R. (ed.), Wzrost gospodarczy w krajach transformacji: konwergencja czy dywergencja? [Economic Growth in Transition Economies: Convergence or Divergence?]. PWE, Warsaw, 2009.

Rodrick, D., Institutions, Integration, and Geography: In Search of the Deep Determinants of Economic Growth, "Weatherhead Center for International Affairs", Harvard University, pp. 5-9, 2002. 
Rodrik, D., Subramanian, A., Trebbi, F., Institutions Rule: The Primacy Of Institutions Over Geography And Integration In Economic Development, "Journal of Economic Growth",Vol. 9, No 2, pp. 5-23, 2004.

Sachs, J. D., Globalization and Patterns of Economic Development, Institut für Weltwirtschaft an der Universität, Kiel, 2000.

Sachs, J. D., Warner, A., Economic Reform and the Process of Global Integration, "Brooking Papers on Economic Activity", No 1, pp.5-63, 1995.

Sala-i-Martin, X., A Classical Approach to Convergence Analysis, "Economic Journal", Vol. 106, No 437, pp. 1019-1036, 1996.

Schadler, S., Mody, A., Abiad, A., Leigh, D., Growth in the Central and Eastern European Countries of the European Union, "International Monetary Fund Occasional Paper", No 252, 2006.

Staňisić, N., The Effects of the Economic Crisis on Income Convergence in the European Union, “Acta Oeconomica”, Vol. 62, pp. 161-182, 2012.

Stawicka, M. K., Perspektywy zrównania poziomu rozwoju gospodarczego Polski i Unii Europejskiej. Prognoza na lata 2010-2040 [Prospects of Equalization of Economic Development of Poland and the European Union: Forecast for the Years 2010-2040], "Zarządzanie i Edukacja”, No 82, pp.33-44, 2012.

Solow, R., A Contribution to the Theory of Economic Growth, "Quarterly Journal of Economics", Vol. 70, No 1, pp. 65-94, 1956.

Vamvakidis, A., How Robust is the Growth-openness Connection? Historical Evidence, "Journal of Economic Growth", Vol. 7, pp. 6-17, 2002.

Walczak, E., Czynniki wzrostu gospodarczego w krajach Unii Europejskiej [Determinants of economic Growth in European Union Member States], „Wiadomości Statystyczne”, No 4, pp. 65-83, 2012.

Wolszczak-Derlacz, J., Does Migration Lead to Economic Convergence in an Enlarged European Market?, "Bank i Kredyt”, No 40, pp. 73-90, 2009.

Received: February 2014, revised: April 2017 